\title{
Sistem Informasi Akuntansi Pendapatan Jasa Dan Penjualan Suku Cadang Pada Bengkel Podomoro Motor Pontianak Berbasis Web
}

\author{
Yulia $^{1}$, Nanda Diaz Arizona ${ }^{2}$, Tasya Anisa ${ }^{3}$
}

\section{Info Artikel}

Diterima Juli 10, 2021

Revisi Agustus 10, 2021

Terbit September 10, 2021

\section{Keywords:}

Design

Accounting Information System, Service Revenue and Sales of Spare Parts

\begin{abstract}
Accounting Information System basically includes information systems related to the accounting system of an institution. Accounting has a function to see, observe the financial condition of an organization whether the organization is profiting or losing. The role of information technology in assisting the accounting process in companies/organizations has been going on for a long time. The main reasons for using IT in accounting are efficiency, time and cost savings. Podomoro Motor Pontianak is a company engaged in the service and sale of vehicle parts whose data processing is still very simple. All sales processes still use handwritten paper, resulting in errors in recording and the resulting reports are not precise and accurate. Therefore, the authors designed an accounting information system for service revenues and sales of spare parts so that they can solve the problems that exist in the company. It is hoped that this computerized system can achieve a better system, effective and efficient as well as accurate reports. The method used is the Waterfall model method, namely there is a needs analysis, design, program code generation, testing and support.
\end{abstract}

\section{Identitas Penulis:}

Yulia $^{1}$, Nanda Diaz Arizona ${ }^{2}$, Tasya Anisa ${ }^{3}$

Universitas Bina Sarana Informatika Program Studi Sistem Informasi Akuntansi Kampus Pontianak

Jalan Abdurrahman Saleh no. 18 A Pontianak

Email: yulia.yla@bsi.ac.id ${ }^{1}$, nanda.ndz@bsi.ac.id ${ }^{2}$, tasya.an@gmail.com $^{3}$

\section{PENDAHULUAN}

Peranan teknologi informasi dalam membantu proses akuntansi dalam perusahaan atau organisasi telah lama berlangsung. Alasan utama pengguna IT dalam akuntansi adalah efesiensi, penghematan waktu dan biaya. Alasan lain termasuk peningkatan efektivitas, mencapai hasil atau output laporan keuangan dengan benar. Alasan lainnya yaitu ditambah dengan perlindungan atas asset perusahaan[3].

Salah satu perangkat IT yang digunakan adalah computer, merupakan alat bantu yang paling canggih dan efisien, sangat membantu dalam meringkas proses kegiatan suatu bidang dan bertujuan untuk mempermudah segala pekerjaan yang ada [4].

Podomoro Motor yang terletak di Jalan Putri Candramidi, Kelurahan Sungai Bangkong, Kecamatan Pontianak Kota, Kota Pontianak, merupakan usaha yang bergerak di bidang jasa service dan penjualan suku cadang kendaraan seperti truk dan mobil. Podomoro Motor berusaha memberikan pelayanan yang terbaik dan memberikan kemudahan bagi customer yang membutuhkan jasa dan layanan perbaikan serta penjualan sparepart. Sistem yang sedang berjalan di Podomoro Motor masih menggunakan sistem pencatatan manual atau belum terkomputerisasi sehinnga kurang efesien, hal ini menyebabkan terjadinya kesalahan dalam pencatatan dan perhitungan pendapatan jasa, penjualan suku cadang dan persediaan yang disebab kan oleh kekeliruan data, sehingga pemilik harus melakukan perhitungan dan pengecekan ulang pada persediaan, untuk melakukan perhitungan dan pengecekan ulang membutuhkan waktu yang cukup lama [1]. Oleh karena itu diperlukan proses komputerisasi sehingga memudahkan untuk menginput data dan transaksi pendapatan jasa [2]. Dengan membuat Sistem berbasis web untuk memudahkan pemilik bengkel melakukan penginputan hingga mencetak laporan pendapatan jasa dan penjualan suku cadang.

Berdasarkan permasalahan yang terjadi pada Podomoro Motor yaitu tentang pendapatan jasa service dan penjualan suku cadang. Maka penulis mengambil judul Tugas Akhir "Sistem Informasi Akuntansi Pendapatan Jasa dan Penjualan Suku Cadang Pada Podomoro Motor Berbasis Web. 


\section{METODE}

\subsection{Metode Pengumpulan Data}

1. Wawancara (Interview)

Penulis mengajukan beberapa pertanyaan kepada Bapak Rico Sebastion selaku pemilik. yang bertujuan untuk mendapatkan informasi yang berhubungan dengan pendapatan jasa dan penjualan suku cadang, sehingga memperoleh data yang diperlukan.

2. Metode Pengamatan (Observasi)

Setelah melakukan sesi wawancara, penulis diperkenankan melakukan observasi untuk melihat proses kerja yang dilakukan oleh Pimpinan beserta mekanik Podomoro Motor.

3. Studi Pustaka

Studi pustaka dilakukan dengan cara mencari referensi yang didapat melalui buku, karya ilmiah, internet dan sumber - sumber lain.

\subsection{Metode Pengembangan Software}

Model Waterfall adalah tahapan dari beberapa fase secara berurutan. Pada prosesnya tahapan yang dilakukan adalah satu per satu diselesaikan terlebih dahulu kemudian melangkah pada tahap berikutnya setelah sepenuhnya selesai. Untuk alasan ini, model waterfall adalah rekursif dalam setiap fase yang dapat diulang tanpa henti sampai saat itu disempurnakan dimulai dari identifikasi masalah, desain sistem, implementasi, testing, uji coba dan maintance. Jika pada tahapan uji coba belum sesuai dengan hasil yang tidak sesuai dengan hasil maka tahapan penelitian akan dilakukan evaluasi mulai identifikasi masa[5].

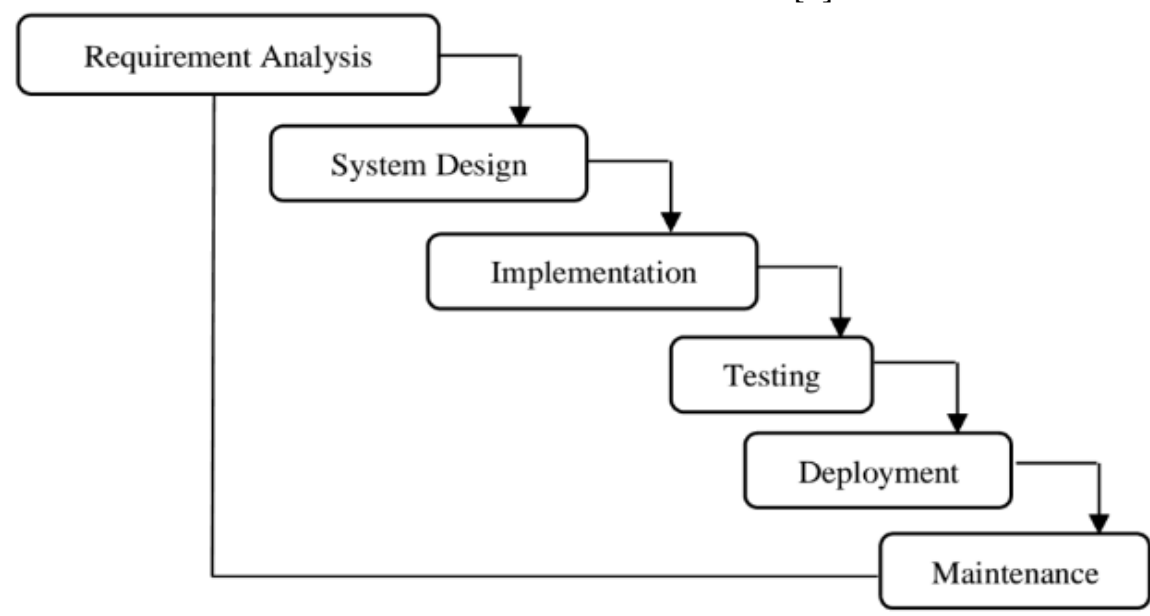

Sumber : Solehatin, \& Anam (2019)

\section{Gambar 1. Metode Waterfall}

Dalam pengembangannya, metode waterfall memiliki beberapa tahapan yang berurut yaitu: requirement (analisis kebutuhan), system design (desain sistem), coding (pengkodean), dan testing (pengujian), penerapan program dan pemeliharaan. Metode yang digunakan dalam pengembangan sistem ini sebagai berikut:

1. Analisa Kebutuhan Software (Halaman Kasir dan Pemilik)

Analisa ini dilakukan agar sistem informasi akuntansi yang dirancang sesuai dengan kebutuhan pengguna. Pada tahap ini penulis melakukan penelitian dengan mencari informasi dari pemilik bengkel yang bertujuan untuk menganalisa kebutuhan sistem informasi yang telah berjalan. Sistem Pendapatan Jasa ini terdiri dari input data pelanggan, input data mekanik, input data transaksi penjualan, input pembayaran, dan Laporan Pendapatan Jasa.

2. Desain Sistem

Pada tahap perancangan basis data penulis menggunakan Entity Relationship Diagram (ERD) untuk merancang relasi antar tabel dalam database dan kemudian dikonversi kedalam bentuk Logical Record Structure (LRS).

3. Pembuatan Kode Program

Penulis merancang sistem informasi Pendapatan Jasa dan Penjualan Suku Cadang berbasis web menggunakan bahasa pemrograman yaitu PHP.

4. Testing (Black Box Testing)

Black box testing adalah tahapan pengujian yang dilakukan pada halaman login admin, form input data customer, dan form data laporan pendapatan.

5. Pendukung (support)

Setelah dilakukann beberapa fase diatas maka perlu diadakan pendukung terhadap sistem yang dibuat. 


\section{HASIL}

\subsection{Proses Bisnis Sistem Berjalan}

1. Proses Pendaftaran Service

Kegiatan ini di mulai dengan customer datang ke bengkel, lalu menyampaikan keluhan kendaraan ke Asisten pemilik.

2. Prosedur Pengecekan

Asisten pemilik menyampaikan keluhan ke mekanik, kemudian mekanik melakukan pengecekan kendaraan, lalu mekanik menemukan kerusakan yang terjadi pada kendaraan tersebut kemudian mekanik menginformasikan kepada pihak customer apakah ingin adanya pergantian suku cadang yang terjadi kerusakan atau tidak. Jika terjadi adanya penggantian suku cadang maka mekanik harus menanyakan terlebih dahulu kepada Asisten Pemilik mengenai ada atau tidaknya stok suku cadang atas kerusakan yang terjadi pada kendaraan customer jika ada stok barang tersebut dan dilakukan pergantian maka mekanik harus melakukan pelaporan kepada Asisten Pemilik untuk ditambahkan kedalam nota pembayaran.

3. Proses pembuatan nota dan laporan

Asisten Pemilik melakukan pembuatan nota pembayaran atas jasa servis dan laporan penjualan suku cadang.

4. Proses penerimaan laporan bulanan.

Pemilik bengkel menerima laporan pendapatan dan penjualan suku cadang yang terjadi setiap bulannya.

\subsection{Activity Diagram}

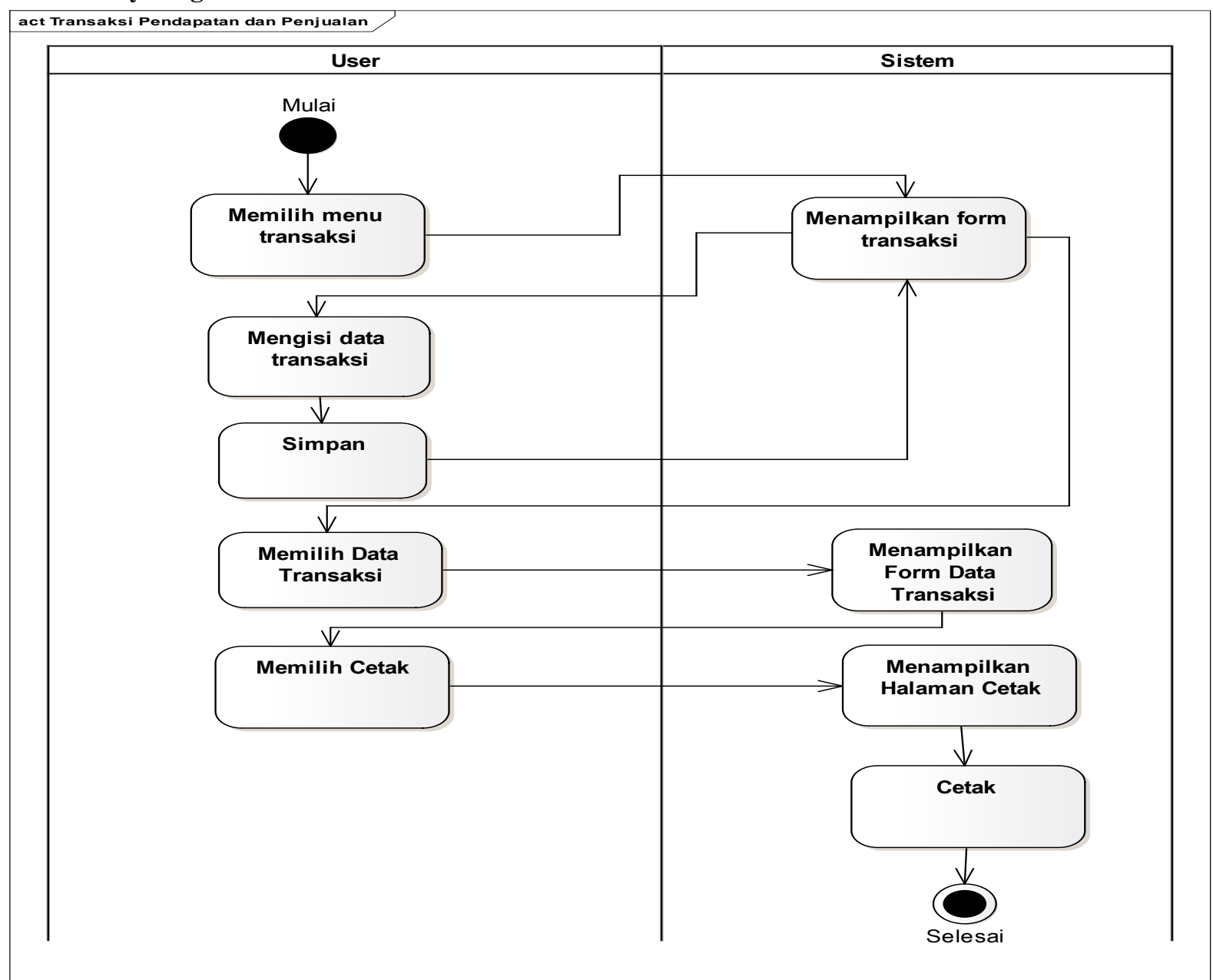

Sumber : Hasil Penelitian (2021)

\section{Gambar 2 Activity Diagram}

Pada Activity Diagram User mengelola Data Transaksi ini menjelaskan aktivitas yang dilakukan oleh Asisten Pemilik, Asisten pemilik memilih Menu Transaksi, sistem menampilkan form Transaksi, user mengisi data transaksi kemudian klik simpan, sistem akan menampilkan kembali form transaksi awal, kemudian user memilih Data transaksi dan sistem akan menampilkan data transaksi selanjutnya user memilih tombol cetak dan sistem mencetak nota. 


\subsection{Squence Diagram}

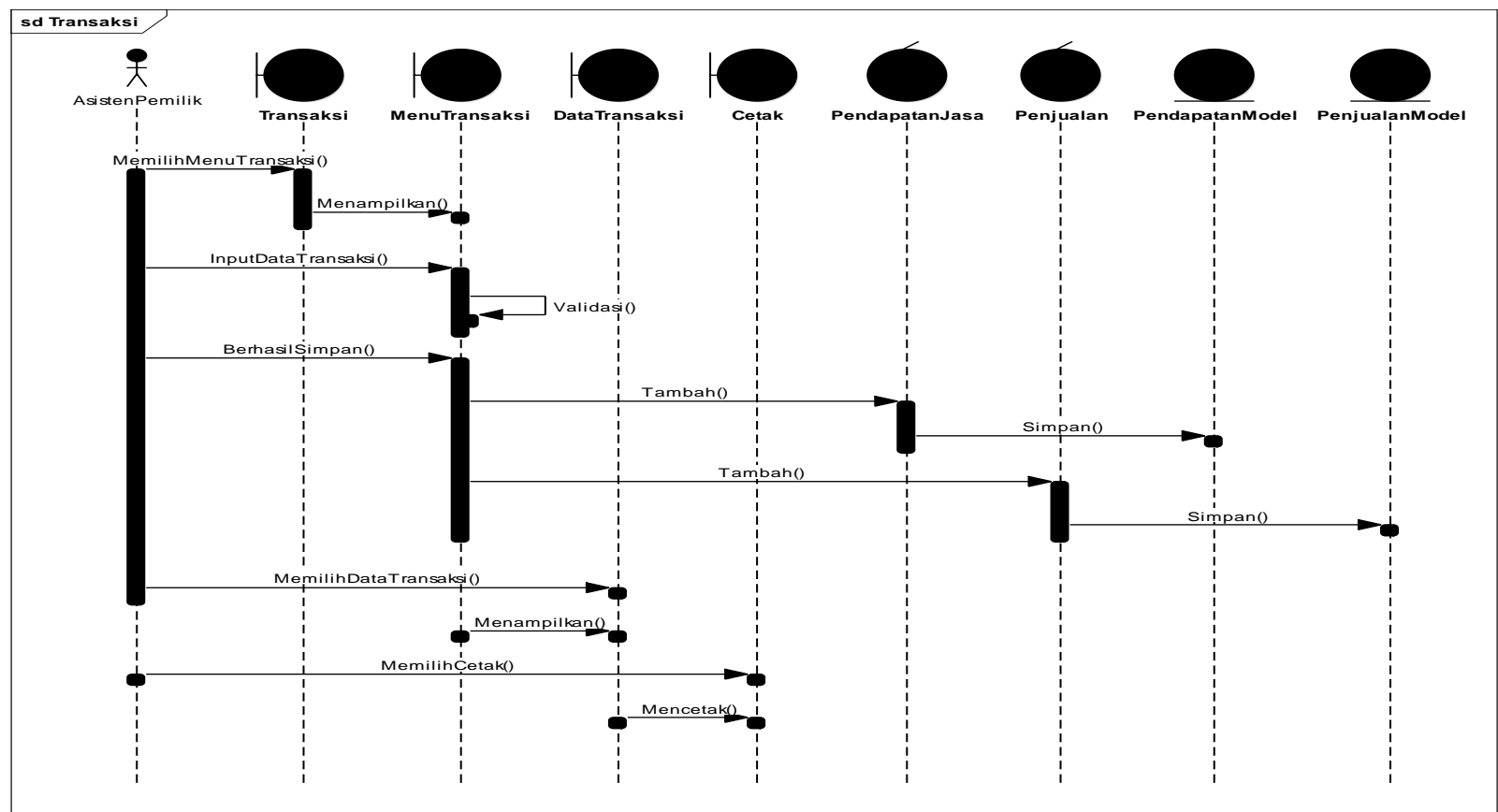

Sumber : Hasil Penelitian (2021)

Gambar 3 Sequence Diagram Mengelola Transaksi

Pada Sequence Diagram Mengelola Transaksi Pendapatan dan penjualan menggambarkan dimana asisten pemilik dapat mengelola Transaksi Penjualan dan Pendapatan, asisten pemilik juga dapat Membuat data transaksi, mencetak dan menghapus transaksi.

\subsection{Entity Relationship Diagram (ERD)}

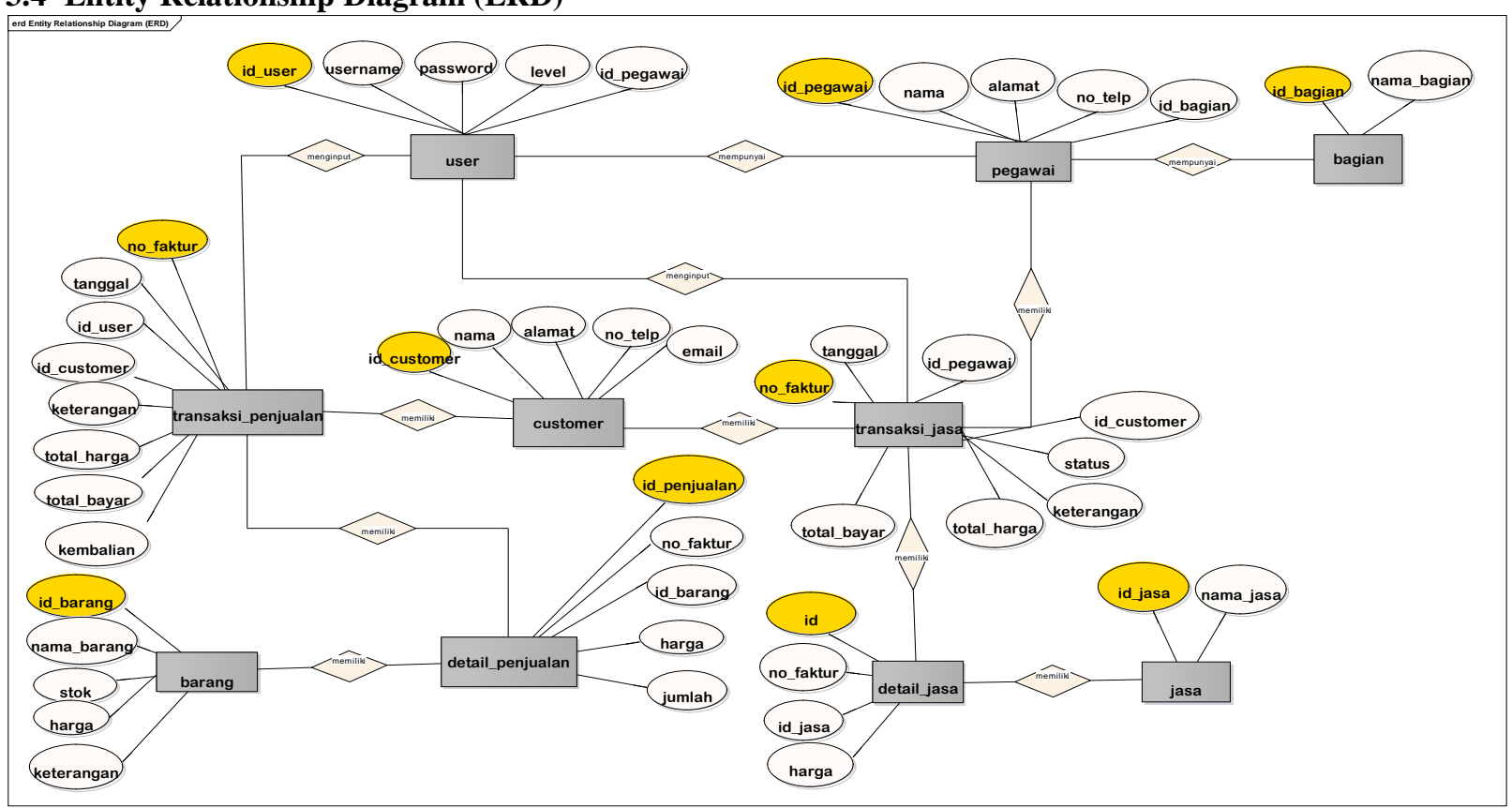

Sumber : Hasil Penelitian (2021)

Gambar 4 Entity Relationship Diagram (ERD)

Pada Entity Relationship Diagram (ERD) diatas menjelaskan terdapat sepuluh tabel pada database yaitu tabel User, Pegawai, Bagian, Barang, Customer, Jasa, Penjualan, Transaksi_Jasa, Detail_penjualan, Detail_jasa. 
Vol. 02, No. 02, September 2021, pp. 86 94

E-ISSN: 2721-7523

\subsection{Logical Record Structure (LRS)}

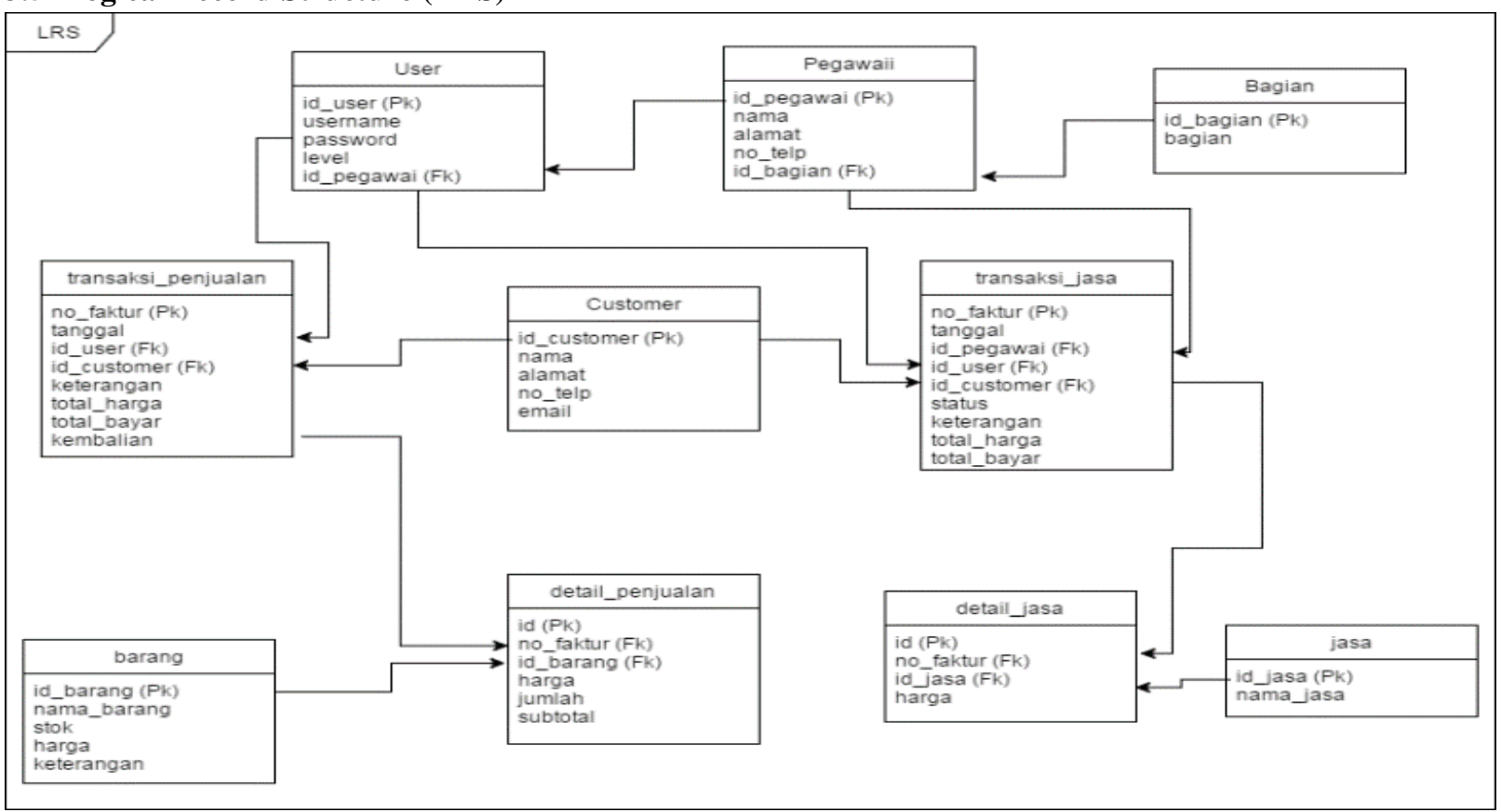

Sumber : Hasil Penelitian (2021)

Gambar 5 Logical Record Structure (LRS)

Pada Logical Record Structure (LRS) diatas menjelaskan terdapat sepuluh tabel pada database yaitu tabel User, Pegawai, Bagian, Barang, Customer, Jasa, Penjualan, Transaksi_Jasa, Detail_penjualan, Detail_jasa.

\subsection{Class Diagram}

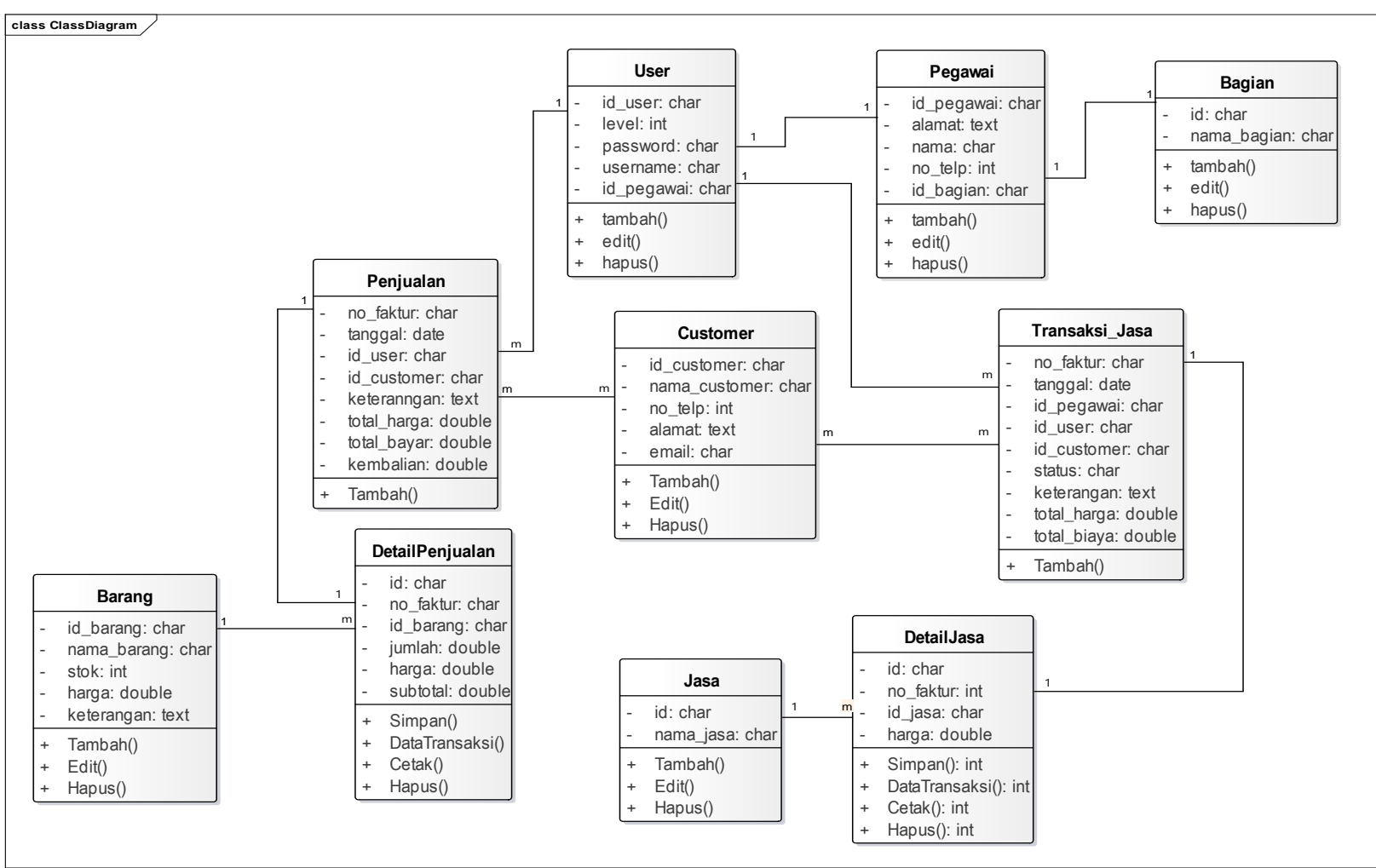

sumber : Hasil Penelitian, 2021

\section{Gambar 6 Class Diagram}


Vol. 02, No. 02, September 2021, pp. 86 94

E-ISSN: 2721-7523

\subsection{User Interface}

1. Halaman Login

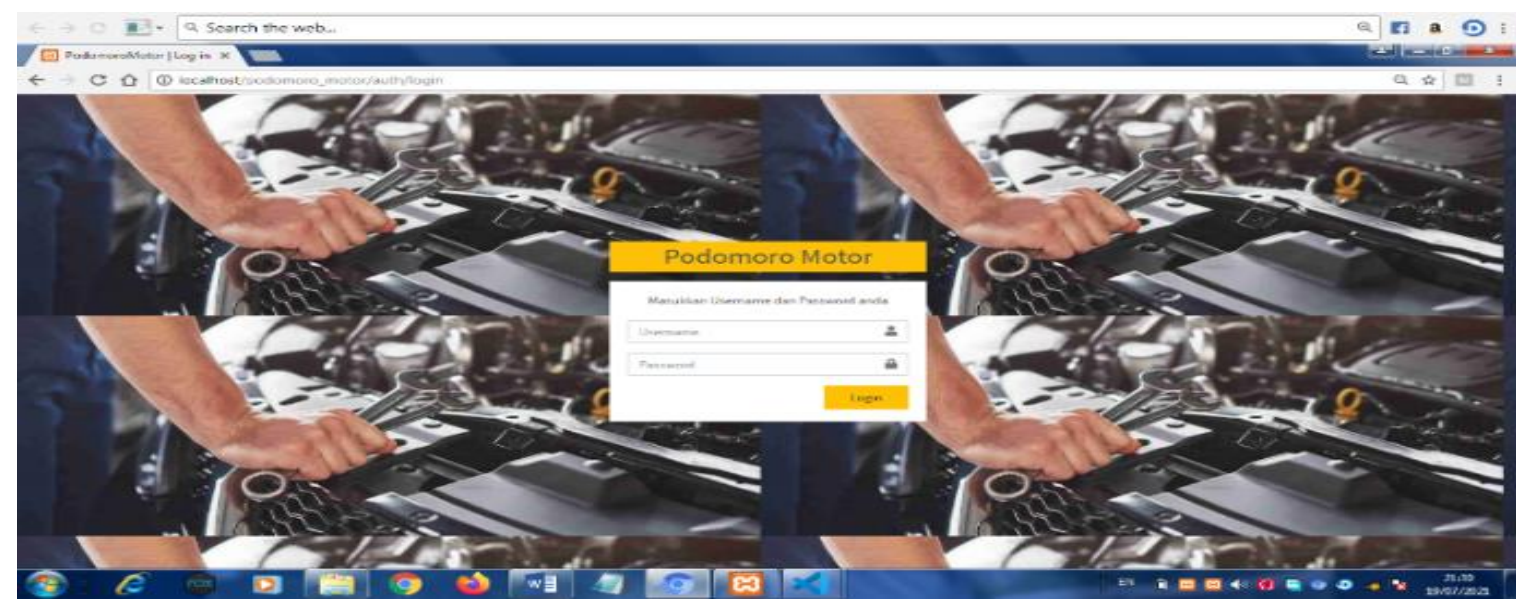

Sumber : Hasil Penelitian, 2021

\section{Halaman Home}

Gambar 7 User Interface Halaman Login

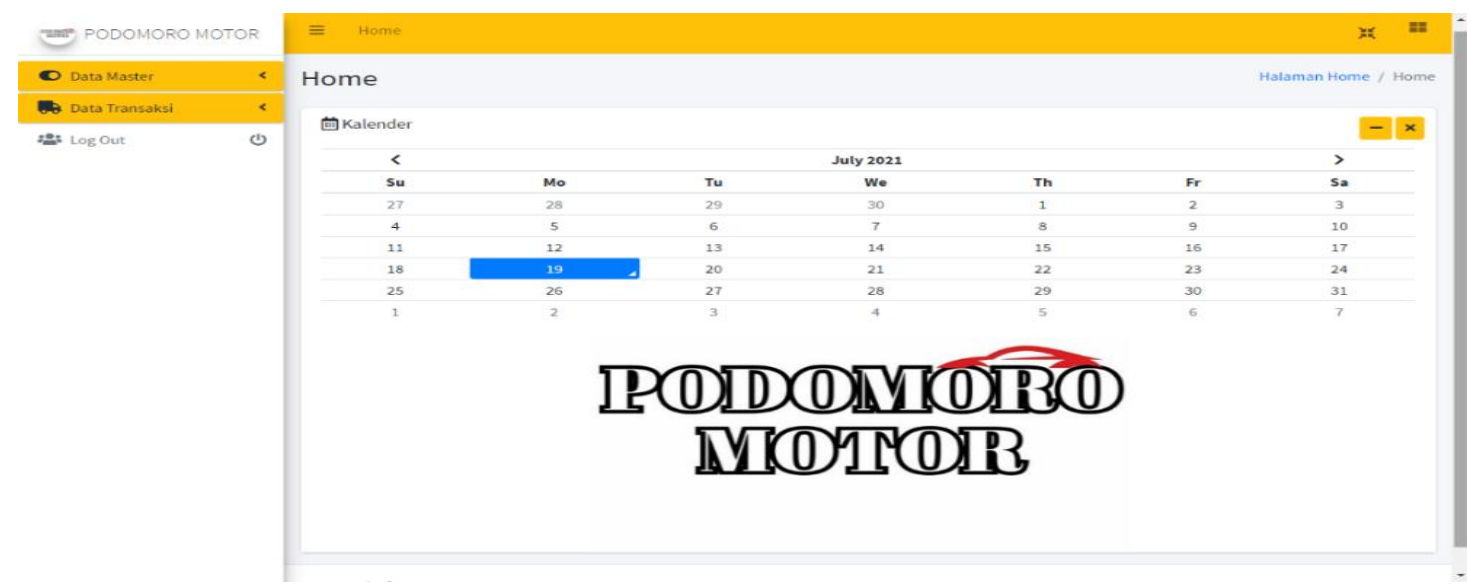

Sumber : Hasil Penelitian (2021)

Gambar 8 User Interface Halaman Home

User Interfase Halaman Home, menampilkan halaman home yang terdapat kalender dan logo Podomoro Motor, Beserta data master, data transaksi, laporan dan logout.

3. Halaman Form Transaksi Penjualan Suku Cadang

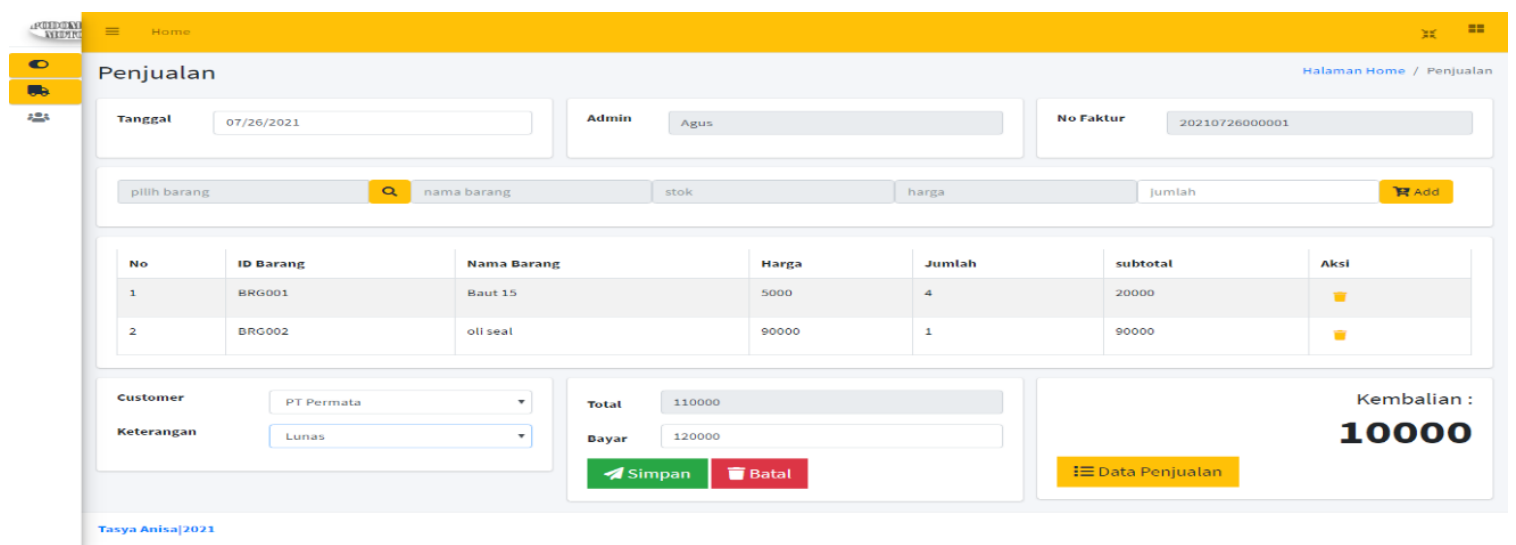

Sumber : Hasil Penelitian, 2021

Gambar 9 Halaman Form Transaksi Penjualan Suku Cadang

User Interface Halaman Form Transaksi Penjualan, menampilkan form transaksi penjualan dimana Asisten Pemilik dapat menginput transaksi penjualan. 


\section{Halaman Data Transaksi Penjualan Suku Cadang}

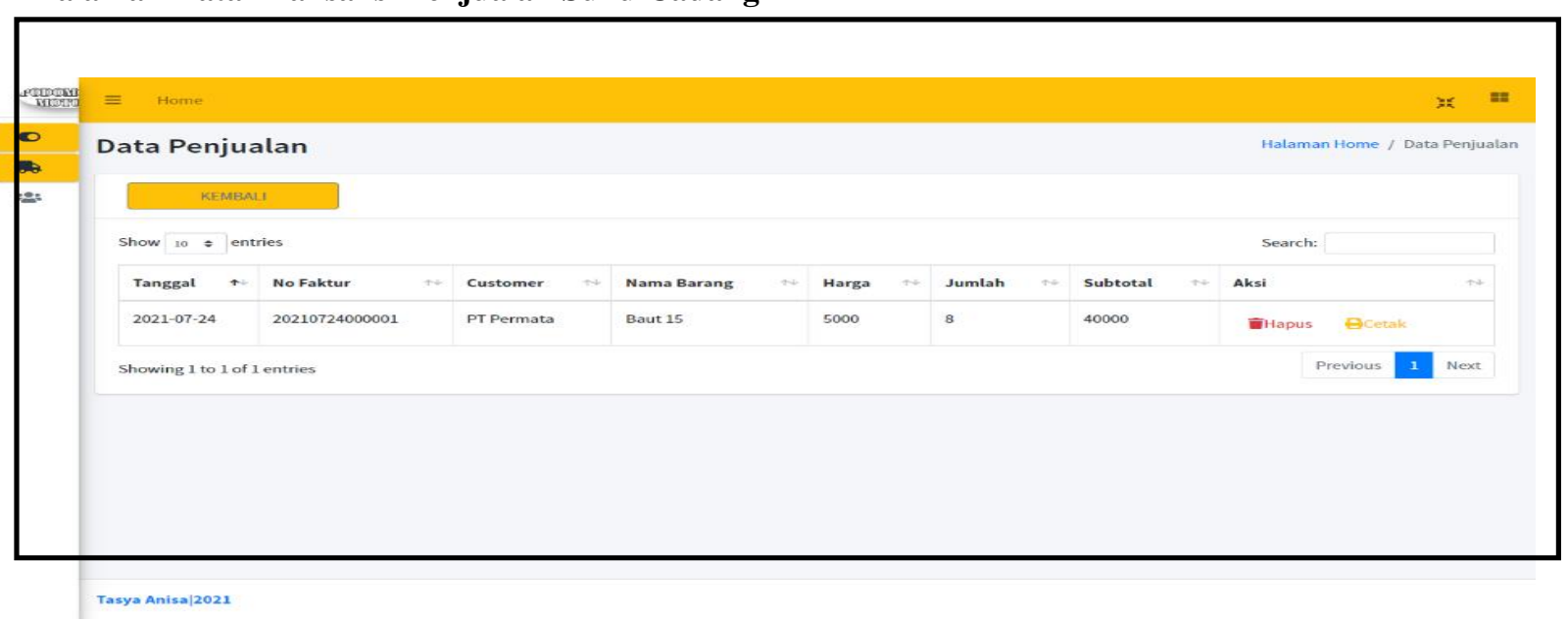

Sumber : Hasil Penelitian (2021)

Gambar 10 Halaman Data Transaksi Penjualan Suku Cadang

User Interface Halaman Form Transaksi Penjualan Suku Cadang, menampilkan form transaksi Penjualan Suku Cadang dimana Asisten Pemilik dapat menginput transaksi Penjualan.

5. Halaman Cetak Transaksi Penjualan Suku Cadang

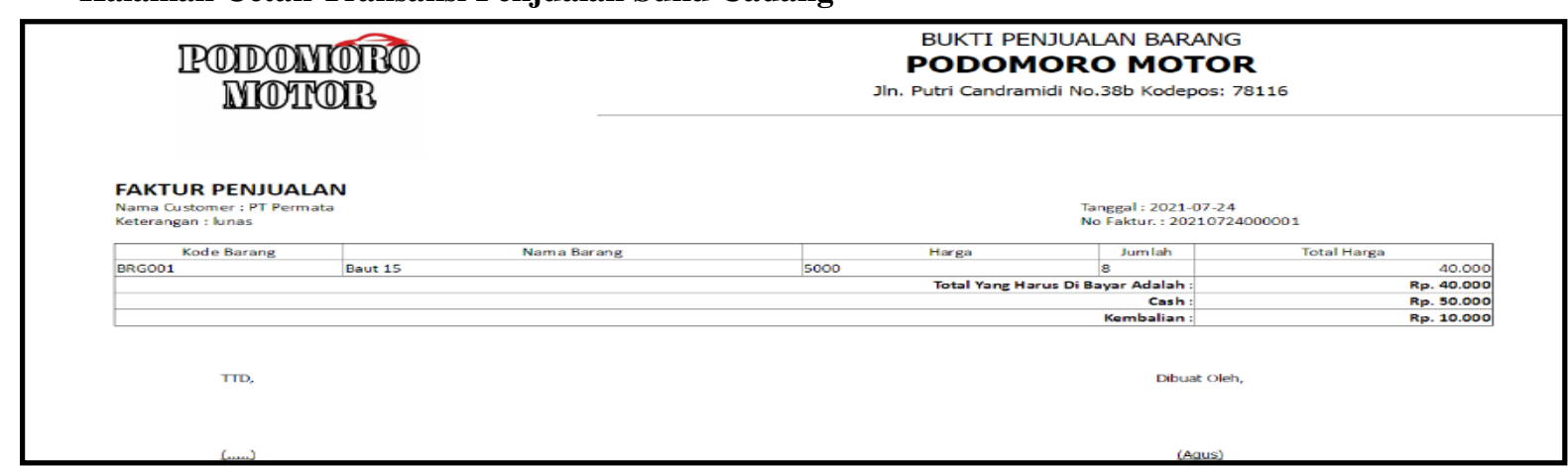

Sumber : Hasil Penelitian, 2021

\section{Gambar 11 Halaman Cetak Transaki Penjualan Suku Cadang}

User Interface Halaman Form Cetak Transaksi Penjualan Suku Cadang, menampilkan form cetak transaksi Penjualan Suku Cadang dimana Asisten Pemilik dapat mencetak transaksi Penjualan.

\section{Halaman Menu Laporan Penjualan Suku Cadang}

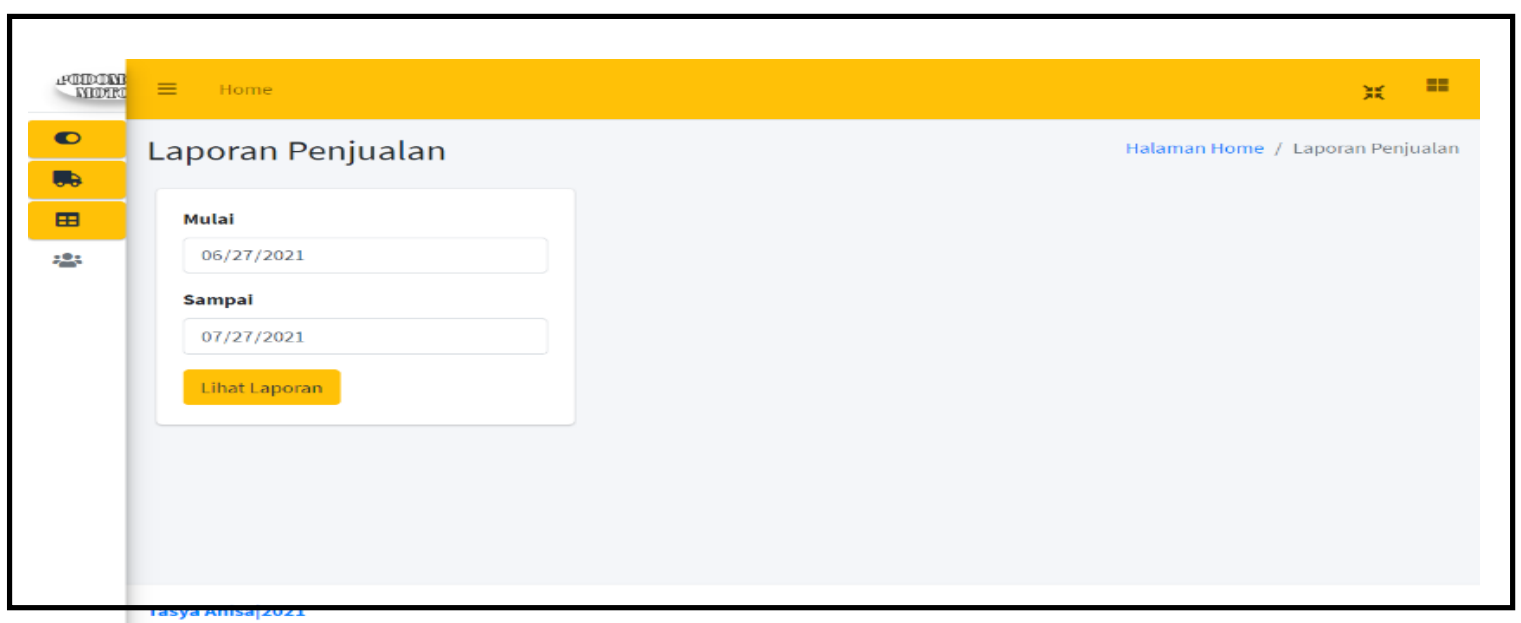

Sumber : Hasil Penelitian, 2021

Gambar 12 Halaman Menu Laporan Penjualan Suku Cadang 
User Interface Halaman Menu Laporan Penjualan Suku Cadang, menampilkan form pemilihan tanggal laporan Penjualan.

\section{Halaman Form Detail Laporan Penjualan Suku Cadang}

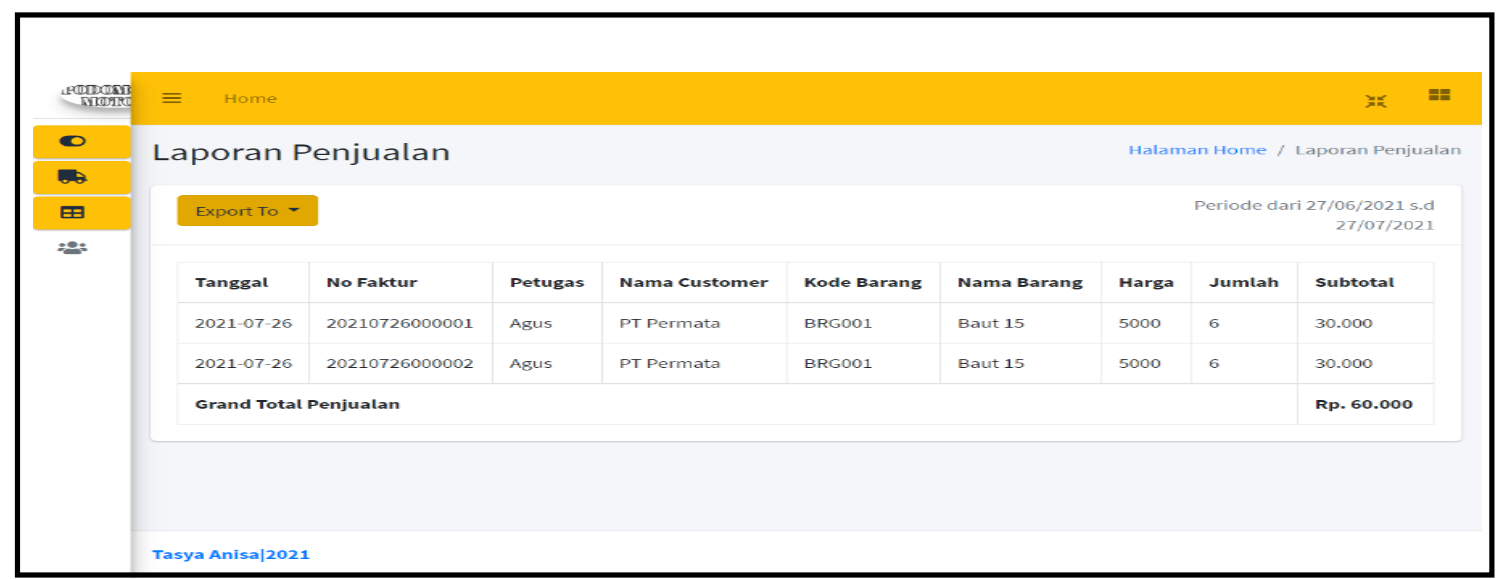

Sumber : Hasil Penelitian, 2021

Gambar 13 Halaman Form Detail Laporan Penjualan Suku Cadang

User Interface Halaman Form Detail Laporan Penjualan Suku Cadang, menampilkan form Detail laporan Penjualan Suku Cadang dimana Asisten dan Pemilik dapat Melihat laporan Penjualan.

\section{Halaman Cetak Laporan Penjualan Suku Cadang}

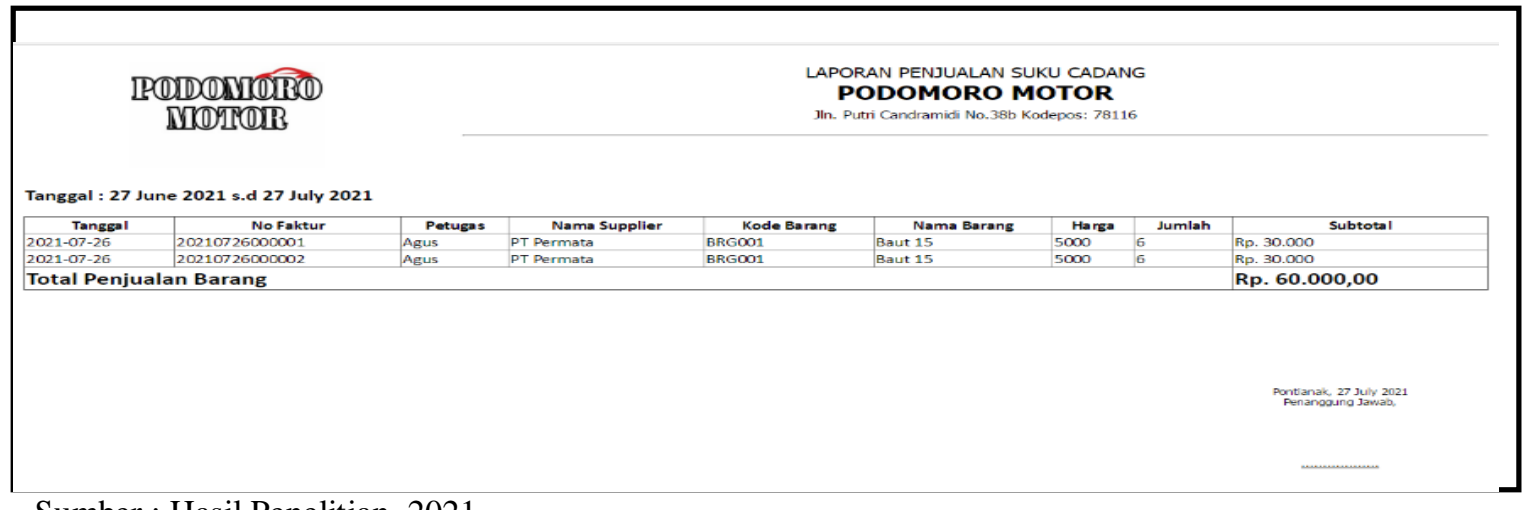

Sumber : Hasil Penelitian, 2021

Gambar 14 Halaman Cetak Laporan Penjualan Suku Cadang

User Interface Halaman Form Cetak Laporan Penjualan Suku Cadang, menampilkan form cetak laporan Penjualan Suku Cadang dimana Asisten dan Pemilik dapat mencetak laporan Penjualan.

\subsection{Blackbox Testing Data Penjualan}

\begin{tabular}{|c|c|c|c|c|c|}
\hline No. & Skenorio Pengujian & Test Case & $\begin{array}{ll}\text { Hasil } & \text { Yang } \\
\text { Diharapkan } & \end{array}$ & $\begin{array}{l}\text { Hasil } \\
\text { Pengujian }\end{array}$ & Kesimpulan \\
\hline 1 & $\begin{array}{l}\text { Tanggal, Admin, Nomor } \\
\text { Faktur, detail penjualan, } \\
\text { customer, keterangan total, } \\
\text { bayar kembalian }\end{array}$ & $\begin{array}{l}\text { Tanggal (terisi) } \\
\text { Admin (terisi) } \\
\text { Nomor faktur (terisi) } \\
\text { Detail penjualan } \\
\text { (kosong) } \\
\text { Customer (kosong) } \\
\text { Keterangan (kosong) } \\
\text { Total (kosong) } \\
\text { Bayar (kosong) }\end{array}$ & $\begin{array}{l}\text { Sistem akan } \\
\text { menolak akses dan } \\
\text { menampilkan } \\
\text { pesan }\end{array}$ & $\begin{array}{l}\text { Sesuai } \\
\text { harapan }\end{array}$ & valid \\
\hline 2 & $\begin{array}{l}\text { Menginput data detail } \\
\text { penjualan tanpa menginput } \\
\text { customer, keterangan bayar }\end{array}$ & $\begin{array}{l}\text { Detail penjualan } \\
\text { (terisi) } \\
\text { Customer (kosong) } \\
\text { Keterangan (kosong) }\end{array}$ & $\begin{array}{lr}\text { Sistem } & \text { akan } \\
\text { menolak } & \text { dan } \\
\text { menampilkan } & \\
\text { pesan } & \\
\end{array}$ & $\begin{array}{l}\text { Sesuai } \\
\text { harapan }\end{array}$ & valid \\
\hline
\end{tabular}

https://ejournal.bsi.ac.id/ejurnal/index.php/justian 


\begin{tabular}{|l|l|l|l|l|l|}
\hline & $\begin{array}{l}\text { Status (kosong) } \\
\text { Bayar (kosong) }\end{array}$ & & & \\
\hline
\end{tabular}

\section{KESIMPULAN}

Sistem informasi akuntansi Pendapatan dan Penjulan yang diusulkan mampu mempersingkat waktu pencatatan, melakukan pengecekan, dan perhitungan suku cadang serta melakukan penginputan hingga mencetak laporan pendapatan jasa dan penjualan suku cadang. Pada system ini terdapat pembatasan hak akses terhadap sistem sehingga dapat menghindari pihak-pihak yang tidak berwenang untuk mengakses data dengan bebas. Dengan diterapkannya sistem komputerisasi maka akan mempermudah asisten dan pemilik untuk mendapatkan data dan informasi yang dibutuhkan.

\section{UCAPAN TERIMA KASIH}

Penulis menyadari bahwa tanpa bimbingan dan dorongan dari semua pihak, maka jurnal ini tidak akan lancar. Oleh karena itu, pada kesempatan ini penulis ingin menyampaikan terima kasih kepada :

1. Rektor Universitas Bina Sarana Infomatika.

2. Wakil Rektor 1 Bidang Akademik Universitas Bina Sarana Informatika.

3. Dekan Fakultas Teknik dan Infomasi Universitas Bina Sarana Informatika.

4. Ibu Lisnawaty, ST, M.Kom Selaku Ketua Program Studi Sistem Informasi Akuntansi Kampus Kota Pontianak, Fakultas Teknik dan Informasi Universitas Bina Sarana Informatika Kota Pontianak.

5. Staf dan karyawan di lingkungan Koperasi Sinar Kalimantan.

6. Ibu Windi Irmayani SE. M.Kom selaku Editor Jurnal Sistem Informasi Akuntansi

7. Rekan-rekan Dosen Universitas Bina Sarana Infomatika PSDKU Pontianak

8. Serta semua pihak yang telah membantu penulis dalam menyelesaikan jurnal ini yang tidak dapat disebutkan satu persatu.

\section{REFERENSI}

[1] Adwiya, R., Arizona, N. D., Pambudi, M. R., Bina, U., \& Informatika, S. (2019). Sales And Purchase Of Website Based Heavy Equipment Sparepart. Jurnal Teknologi Dan Manajemen Informatika, 5(1).

[2] Irmayani, W., \& Utami, R. D. (2020). Pengelolaan Keuangan Berbasis Web PT . Mutualplus Global Resources Cabang Pontianak. 01(01), 40-49.

[3] Mardia, Rahman. Tanjung, Abdul. Karim, Marthinus. Ismail, Elmor. Benedict Wagiu, Eko. Sudarmanto, Supitriyani, Jay. Idoan Sihotang, Sri. Martina, Elfina. Okto Posmaida Damanik, Bonaraja. Purba, D. P. Y. A. (2021). Sistem Informasi Akuntansi dan Bisnis. Yayasan Kita Menulis.

[4] Nasihin. Muhamad, Yulia, N. D. Arizona. (2020). Sistem Informasi AKUNTER ( Akuntansi Terpadu) Berbasis Web Sebagai Pengelolaan Transaksi Keuangan Pada Mutiara Laundry. 6(3), 401-407.

[5] Solehatin, \& Anam, C. (2019). E-Quisioner Terhadap Tingkat Pemanfaatan Layanan Wi-Fi Kabupaten Banyuwangi. Deepublish. 